Policy Research Working Paper 2283

New Tools and New Tests in Comparative Political Economy

The Database of Political Institutions

Thorsten Beck

George Clarke

Alberto Groff

Philip Keefer

Patrick.Walsh
Some say that democracy is

more likely to survive under

parliamentary governments.

That result is not robust to the use of different variables from

the Database of Politicail

Institutions, a large new

cross-country database that

may illuminate many other

issues affecting and affected

by political institutions.

The World Bank

Development Research Group

Regulation and Competition Policy

February 2000 


\section{Summary findings}

This paper introduces a large new cross-country database on political institutions: the Database on Political Institutions (DPI).

Beck, Clarke, Groff, Keefer, and Walsh summarize key variables (many of them new), compare this data set with others, and explore the range of issues for which the data should prove invaluable.

Among the novel variables they introduce:

- Several measures of tenure, stability, and checks and balances.

- Identification of parties with the government coalition or the opposition.

- Fragmentation of opposition and government parties in legislatures.

The authors illustrate the application of DPI variables to several problems in political economy.
Stepan and Skach, for example, find that democracy is more likely to survive under parliamentary governments than presidential systems. But this result is not robust to the use of different variables from the DPI, which raises puzzles for future research.

Similarly, Roubini and Sachs find that divided governments in the OECD run higher budget deficits after fiscal shocks. Replication of their work using DPI indicators of divided government indicates otherwise, again suggesting issues for future research.

Among questions in political science and economics that this database may illuminate: the determinants of democratic consolidation, the political conditions for economic reform, the political and institutional roots of corruption, and the elements of appropriate and institutionally sensitive design of economic policy.

This paper - a product of Regulation and Competition Policy, Development Research Group - is part of a larger effort in the group to understand the institutional bases of poverty alleviation and economic reform. The study was funded by the Bank's Research Support Budget under the research project "Database on Institutions for Government Decisionmaking" (RPO 682-79). Copies of this paper are available free from the World Bank, $1818 \mathrm{H}$ Street, NW, Washington, DC 20433. Please contact Paulina Sintim-Aboagye, room MC3-422, telephone 202-473-8526, fax 202-522-1155, email address psintimaboagye@worldbank.org. Policy Research Working Papers are also posted on the Web at www.worldbank.org/ research/workingpapers. The authors may be contacted at tbeck@worldbank.org, gclarke@worldbank.org, pkeefer@worldbank.org, or pwalsh@worldbank.org. February 2000. (46 pages)

The Policy Research Working Paper Series disseminates the findings of work in progress to encourage the exchange of ideas about development issues. An objective of the series is to get the findings out quickly, even if the presentations are less than fully polished. The papers carry the names of the authors and should be cited accordingly. The findings, interpretations, and conclusions expressed in this paper are entirely those of the authors. They do not necessarily represent the view of the World Bank, its Executive Directors, or the countries they represent. 


\title{
New Tools and New Tests in Comparative Political Economy: The Database of Political Institutions
}

\author{
Thorsten Beck, George Clarke, Alberto Groff, \\ Philip Keefer, and Patrick Walsh
}

Beck, Clarke, Keefer and Walsh: Development Research Group, The World Bank. Groff: Federal Department of Foreign Affairs (Switzerland).

This paper's findings, interpretations, and conclusions are entirely those of the authors and do not necessarily represent the views of the Federal Department of Foreign Affairs, or the World Bank, its Executive Directors, or the countries they represent. 


\section{Introduction}

The investigation of the institutional and political roots of government decisions has accelerated rapidly in the last twenty or more years. However, cross-country empirical work has been handicapped by a lack of detailed data on the political and institutional characteristics of countries, and their change over time. Comparative political economy, therefore, has been restricted to small-sample case studies, important in their own right, but imposing unavoidable limits on researchers seeking to generalize their results beyond the case study sample.

The lack of data has been a serious obstacle to better understanding of numerous areas. in political economy, including the political conditions under which governments promote rather than retard economic development. Despite evidence that institutions underpin economic development, we are still far away from the answers to two fundamental questions: Which political institutions are most conducive to development and reform? And under what conditions do such institutions emerge? Unfortunately, cross-country data that could help to answer these questions, data that provided a disaggregated picture of a country's political institutions and operations, have been scarce. In this article we introduce a new data set that fills many of these data gaps, the Database on Political Institutions (DPI). It has been compiled in the Development Research Group of the World Bank, but it rests on an intellectual foundation laid by a large body of political economy research.

The DPI contains 113 variables (detailed in Annex 1) for 177 countries over the years 1975-95. The variables provide details about elections, electoral rules, type of political system, party composition of the opposition and government coalitions, and the extent of military influence on government. The DPI also contains a number of new variables, compiled from 
the raw data, including original measures of checks and balances and political stability.

In contrast to other databases, these variables are nearly all objective and their construction is entirely transparent. They are also disaggregated, allowing researchers to get away from such useful but broad indicators of countries as whether they allow elections or not, whether elections are "free", or whether the executive is "constrained." Instead, the DPI allows researchers to use precise and concrete institutional features of countries, and to combine them in ways appropriate to theories they are examining.

In this paper, we identify numerous and policy-relevant research directions where this data will be helpful. We also describe the different variables and demonstrate their utility in several applications. For example, we find that earlier results concerning the impact of divided government on public debt (Roubini and Sachs, 1989), and the impact of presidentialism vs. parliamentarism on democratic consolidation (Stepan and Skach, 1993), change considerably when their methodologies are replicated using the DPI's variables on divided government, presidentialism and parliamentarisrn. The remainder of the paper, and the annexes, provide details on sources and collection methodology.

The need for cross-country institutional data

- A large and diverse array of inquiries into the political economy of economic development and the determinants of institutional change have been hindered by the absence of detailed cross-national objective data on the institutional and political characteristics of countries. A few of the areas of investigation to which the DPI can contribute are outlined here.

Political Business Cycles. Research on the existence and importance of a political business cycle has largely focused on a select group of developed countries. One reason for the narrow 
focus has been the absence of election data in a larger sample of countries. The Database on Political Institutions has election dates (month and year) and election winners and losers for more than 150 countries since 1975. Both legislative and executive elections are included, as is the composition of governments both before and after elections.

Checks and balances: stability versus decisiveness. The contribution of political institutions to economic policy outcomes is another important area of research. For example, divided governments or checks and balances are thought to have conflicting influences on economic development. One line of research suggests that they encourage budget deficits and delay reactions to crisis. Another line of work finds that they increase the predictability and restraint with which governments regulate firms and citizens. Research on the first topic (e.g., by Roubini and Sachs) focuses on a selected group of OECD countries. Research on the second issue has relied on case studies (for example, North and Weingast, 1989, study the introduction of institutional checks following the Glorious Revolution in England), or on subjective data, such as the extent of "executive constraints" in a country (e.g., Keefer and Knack, 1997). The DPI includes several objective measure of checks and balances that permit the impact of this institutional feature of countries to be systematically analyzed, and the tradeoffs between stability and decisiveness to be investigated. Electoral rules, policy maker incentives, and corruption and fiscal policy. Another set of theories in political economy predict that pork barrel spending and corruption will vary systematically both with the number of decision makers (Rasmusen and Ramseyer, 1994) and with the electoral rules by which decision makers are selected (Cox and McCubbins, forthcoming). Tests of these theories are made difficult by the absence of cross country data on both of these institutional dimensions. This data set goes some distance in remedying this 
problem. First, it provides a better approximation of the number of key decision makers in a country through two variables on the number of checks and balances. Second, it presents information on voting rules in countries, including the use of plurality and/or proportional systems, closed or open list systems, threshold or D'Hondt systems, and the relative dominance of these systems if more than one is used.

Political stability, political tenure, and government policy. Government officials may also make decisions that retard development because their policy horizons are limited to their time in office. The shorter the horizon of officials, the more likely it is that they will take actions with significant long-run costs to obtain modest short-run benefits. All existing analyses of the impact of leader horizons (for example, Alesina, et al., 1996,and Clague, et al., 1996) rely on executive turnover measures. However, in systems in which the prime minister or president is not the only veto player, these turnover measures present a biased picture of the horizons of all veto players. In particular, in countries with multiple veto players, the replacement of a president, prime minister, or even a cabinet, does not always mean that all veto players from the previous government have changed. Often, some of the parties that exercised a veto role in earlier governments reappear in successor coalitions. This database allows more nuanced turnover indicators to be constructed, and presents two such indicators. Civil war, etbnic conflict and political institutions. The conditions under which ethnic groups are in conflict and that this conflict leads to violence are a continuing and important focus of research (see, e.g., Collier and Hoeffler, 1999). However, political institutions are likely to have both a significant influence on whether ethnic groups encounter conflicts of interest and on whether those conflicts precipitate violence. Institutions affect whether different groups have a voice in the allocation of state resources; they also affect the credibility 
of assurances provided by one ethnic or other interest group to another (Weingast, 1998). The DPI has information bearing on both of these issues.

Electoral rules, such as voting thresholds and other choices regarding the aggregation of votes, influence whether minority interests are more or less likely to be influential in the formation and dissolution of governments - and hence, more or less likely to abandon formal, institutional channels for the resolution of their grievances. Similarly, the existence of multiple veto players - checks and balances - should make it more likely that any given ethnic or other interest group has the ability to block state actions that are to its detriment. This is the essence of institutional arrangements that enhance credibility. Electoral competitiveness and policy outcomes. To the extent that the "losers" from economic reform are politically influential - are key constituents of political decision makers - reform is less likely. This is a truism of political economy, but it leads to a still unanswered question: are politicians most likely to favor constituents who were supporters in past elections but deserted them recently; those whose support is up for grabs and could swing the next election one way or the other; or core supporters who never abandon them under any circumstances? All of these possibilities receive some theoretical and empirical support (see Dixit and Londregan, 1996, and Schady, 1998).

A simpler question, which is similarly unanswered, is whether greater competition in contests for political office increases or reduces the willingness to reform. Faced with the prospect of more competitive elections, politicians might be more sensitive to redistributive concerns and less likely to reform. However, politicians who feel few competitive pressures to reform may be more likely to engage in policies that benefit them and their core supporters at the expense of the rest of society. In the latter case, greater electoral competitiveness might 
lead to greater willingness to pursue policies that are less disproportionately beneficial to them and their core supporters. Several variables in this database, ranging from indices of electoral competitiveness, to the vote shares of parties and directly elected executives, permit crosscountry investigation into questions such as these.

Poverty alleviation and voice. The construction of a safety net for the poor, or of programs that allow the poor to build human and financial capital to rise out of poverty, is often distorted by political imperatives. Pritchett and Gelbach (1997), for example, have provided evidence and theory indicating that targeting assistance to the poorest is unsustainable over time. In a simple majority-rule setting, they show that the less poor majority eventually demand more expansive coverage of targeted programs as a condition for their continued support of them. However, the structure of political institutions can mitigate - or exacerbate - this outcome. The rules governing election to the US Congress, for example, give an incentive to legislators representing the inner city and to those representing farming districts to agree on the continued provision of narrowly targeted food stamps. Such incentives are less strong in countries where legislators represent broader segments of society, most of whom gain little or lose from targeted assistance. The DPI contains variables that help to capture some of the institutional features that would affect the sustainability of targeting, including the presence of legislatures and rules governing election to legislative chambers.

Economic tradeoffs in constitution drafting. When tremendous institutional transformations occur, from totalitarianism to democracy, or even from one constitution to another, they entail numerous detailed decisions from among a broad array of institutional choices. Here, again, the empirical evidence that should inform these choices - e.g., which electoral rules? how should the executive be selected? - has been largely unavailable. As a consequence, 
decisions about large issues - should a system be presidential or parliamentary? - and smaller but still important issues - how high should voting thresholds be, which rules of proportional representation should be adopted - tend to rest on intuition and political self-interest, uninformed by empirical evidence about the later consequences of these choices for growth, development, or social conflict. Variables in the DPI should contribute to accelerated empirical research on such questions.

\section{The Variables}

The variables in this dataset provide considerable scope for improving our ability to answer these questions. The more than one hundred different variables can be divided into seven general categories. Each category, if not each variable, is described in this section.

\section{Political system and electoral competitiveness}

Two fundamental characteristics of a political system are the relationship of the executive and legislative branches, and the competitiveness of elections of the political actors who occupy them. The DPI has information on both. With regard to the first, the variable SYSTEM was created to capture whether countries are presidential, assembly-elected presidential, or parliamentary. Determining whether political systems are presidential or not depends on answers to a number of questions. Our judgements are similar to those-of others, but were modified to take into account our particular sources.

The first question is straightforward: is there a single executive elected by popular vote? If both are true, the system is coded as "presidential." However, there are countries in which both a prime minister and a president are in place, or where the executive is elected by the legislature but is called a president and enjoys the same degree of independence from the 
legislature, after election, as the typical popularly-elected president. Countries with these characteristics were coded in the following way.

For chief executives who were called presidents and who were elected by the assembly, as in Bolivia, we ask whether the assembly can easily recall him or her. If they need a twothirds vote to impeach, or are required to dissolve themselves in order to force out the executive, then the country is characterized as having an "assembly-elected president." Otherwise, the country is characterized as "parliamentary."

Where there are both a president and a prime minister, we ask, how likely would it be for the president's view on legislation to prevail over that of the prime minister? This led us to place greater weight on legislative powers of the president. We distinguish whether the system was presidential or parliamentary with a three-part test. First, can the president veto legislation that the parliament can override only with a supermajority? If so, the country is coded as presidential despite the presence of a prime minister. Second, in the event that presidents lack this veto power, we ask whether they can appoint and dismiss cabinet ministers (including the prime minister) and dissolve the assembly. If they can do both, the system is again characterized as presidential. Finally, in those few cases where these details are not revealed in the source material, if the source material refers consistently to the president rather than the prime minister as the important decision maker, the system is again classified as presidential (as in Romania and Kyrgyzstan). The data is thoroughly annotated to identify these rare cases.

These decision rules led us to code Portugal and France as parliamentary rather than presidential systems. Others (Shugart and Carey (1992), Shugart (1995)) place greater weight on non-legislative presidential powers, such as the right to appoint cabinet members, and 
therefore label these countries as presidential. Although policy making in France under divided executive control seems to support our interpretation, legitimate reasons exist to use other categorization criteria. One advantage of the DPI lies in its explicit statement of the rules we employ, allowing researchers to determine more easily the adequacy of variables to their conceptual requirements.

The database also contains variables that characterize the competitiveness of elections in countries. The earlier discussion outlined the potential importance of electoral competitiveness to political economy investigations: the policy choices of politicians are likely to be influenced by the likelihood that those choices will lead to their replacement. In addition, in the creation of checks and balances variables, it matters a great deal whether the legislative and executive branches of government are independent of each other. If legislative elections as a whole are non-competitive, it is usually the case that the executive - or whoever chooses the executive - also exercises decisive influence over the legislature. Consequently, the legislature is less of a check on executive behavior. Finally, investigations of institutional change, particularly of change to more democratic decision making, need to accurately characterize the institutional environment. Knowing the formal, constitutional rules governing countries is one way to characterize democracy; an important supplement is to know whether these rules are applied in practice. The Indices of Electoral Competitiveness address both of these issues.

There are two such indices in the data set, one for executive and one for legislative elections. The core of the two indices is the number of parties that could and did compete in the last election. Ferree and Singh (1999) present the first effort to code such variables, and our indices are based on theirs. They classify 46 African countries on a six point scale (one to six). 
The highest score (six) on their scale goes to countries in which multiple parties compete in elections, even if they do not win seats. For the DPI, we collected sufficient information to replicate this type of indicator for more than 100 additional countries. However, for wider application of their indices we added a seventh point to the scale, in order to identify variation among the large number of countries that exhibit elections where multiple parties run but only one party enjoys great success. Countries receive a seven that have elections in which multiple parties compete and the largest party receives less than 75 percent of the vote. Conceptually, this distinction captures institutional or informal biases against political competitors that are not revealed in our sources; empirically, this seventh category generates much more variability among countries outside of Africa. The scale, then, is:

1 no executive/legislature

2 unelected executive/legislature

3 elected, one candidate

4 one party, multiple candidates

5 multiple parties are legal, but only one worl seats (because other parties did not exist, compete, or win seats).

6 multiple parties competes and won seats (but one party one 75 percent or more of the seats)

7 the largest party received less than 75 percent of the seats.

As with distinctions between presidential and parliamentary systems of government, numerous subtleties arise in assessing scores for these indices. They are thoroughly detailed in the documentation accompanying the database. For example, many countries have executives who are indirectly elected. In our rating scheme, they receive the same competitiveness score as the body that elects them. Therefore, in a parliamentary system, executive elections are as competitive as legislative elections. When there is an electoral college, elections are as competitive as membership in the electoral college. If the executives themselves appoint the electoral college, the systems are scored as two, on a scale of one to seven. Competitively 
elected prime ministers get six or seven. The chief executives of Communist nations (the chairman of the Communist Party) are assigned a three, because they are elected by the Party Congress, an electing body which they do not appoint. Executives elected by small, appointed juntas or by appointed electoral colleges receive a two. Countries that allow referenda on unelected executives are scored as three.

Three other variables supplement these indices. First, elections may be competitive, but the military may nevertheless wield significant power behind the scenes. To get at this, we have two variables indicating whether the chief executive and the minister of defense, respectively, are military officers. Second, our sources often mention voting irregularities or candidate intimidation that are serious enough to affect electoral outcomes, though coverage is far from complete. We record such references irrespective of whether claims that fraudulent elections have occurred are based only on the allegations of the opposition or are supported by independent international observers. Non-constitutional irregularities are also recorded as present when important parties boycott elections or the election results.

One application of these variables is to the debate over whether presidential or parliamentary systems are more likely to lead to democratic consolidation. Stepan and Skach (1993), for example, argue that parliamentary systems are more likely to be associated with long-running democracy than are presidential systems. They offer as evidence the fact that of 53 non-OECD countries, 22 were democratic for at least 10 consecutive years, and of these, 17 were parliamentary. Variables from the DPI suggest a different picture, however. Table 1 indicates a breakdown parallel to theirs using a different indicator of democracy (countries that score at least six on the Legislative Index of Electoral Competitiveness), and the SYSTEM variable, and applying these two variables to a large group of non-OECD countries from 1975 
- 1995. In contrast to their findings, the sample of countries that have experienced at least ten continuous years of democracy is evenly split between presidential and parliamentary systems ( 22 countries in each), rather than weighted in favor of parliamentary systems. Table 1 does not necessarily refute the argument in Stepan and Skach (1993). It does suggest that with more extensive institutional databases, research can begin to accommodate new levels of hypothesisbuilding in institutional analysis, especially hypotheses that can explain such different findings as those in Table 1.

Table 1: Presidentialism, parliamentarism, and democratic consolidation among nonOECD countries

\begin{tabular}{|c|c|c|c|c|}
\hline & & \multicolumn{3}{|c|}{$\begin{array}{l}\text { Regime type during the democratic period } \\
\text { (Legislative Index of Electoral Competitiveness } \\
\text { greater than } 5 \text { ) }\end{array}$} \\
\hline & & Presidential & Parliamentary & $\begin{array}{l}\text { Indirectly- } \\
\text { elected } \\
\text { president } \\
\text { (DPI) or semi- } \\
\text { presidential } \\
\text { (Stepan-Skach) }\end{array}$ \\
\hline \multirow{2}{*}{$\begin{array}{l}\text { Non-OECD countries } \\
\text { that were democratic } \\
\text { at least one year } \\
\text { during } 1975-1995\end{array}$} & $\begin{array}{l}\text { DPI Indicators } \\
\text { (1975 - } 95,122 \\
\text { countries) }\end{array}$ & 68 & 40 & 14 \\
\hline & $\begin{array}{l}\text { Stepan-Skach } \\
\text { (1973-89, } 53 \\
\text { countries) }\end{array}$ & 28 & 25 & 0 \\
\hline \multirow{2}{*}{$\begin{array}{l}\text { Number of non- } \\
\text { OECD countries that } \\
\text { were continuously } \\
\text { democratic for at least } \\
\text { ten consecutive years. }\end{array}$} & $\begin{array}{l}\text { DPI Indicators } \\
(1975-95,47 \\
\text { countries })\end{array}$ & 22 & 22 & 5 \\
\hline & $\begin{array}{l}\text { Stepan-Skach } \\
\text { (1973-89, } 22 \\
\text { countries) }\end{array}$ & 5 & 17 & 0 \\
\hline
\end{tabular}

Note: This replicates Table 3, Stepan and Skach (1993), using variables from the Database on Political Institutions (DPI). Countries are "democratic" if they score more than 5 on the Legislative Index of Electoral Competitiveness. Regime type scores are from the SYSTEM variable, where $0=$ Presidential, $1=$ indirectly elected and 2 - Parliamentary. 


\section{Preferences and parties}

For most political economy questions, one is interested in the structure of political decision making and also in the policy preferences or ideological leanings of decision makers. Preferences are difficult to discern even in a small sample of countries. In the US literature, the most rigorous attempts at assessing preferences have relied on voting records of legislators. In the literature on European politics, impressive progress in comparative politics has been made on the basis of labor-intensive efforts to review and classify the platforms of political parties (see, for example, Laver and Shepsle). For many countries of the world, though, such information is not available, not germane, or not a reliable indicator of decision maker preferences.

A starting point for any analysis that requires preferences of policy makers is the party identification of decision makers. Our data set identifies the party of the prime minister and/or president, the three largest parties in the government coalition, and the largest party in the opposition. In addition, our sources provide useful information for some countries about the policy preferences of key decision makers on five different dimensions: economic, nationalistic, regional, rural, religious. These dimensions were chosen because they do not necessarily correlate with each other: religious or nationalistic parties adopt both left and right wing economic policies; some religious parties are not nationalistic and some are; etc. That is, we intended, where possible, to allow for a multi-dimensional policy space. Coverage is far from exhaustive, unfortunately, but constitutes the most comprehensive characterization of parties and decision makers that can be extracted from the sources upon which we relied.

Detailed information on party platforms (even on the existence of written party platforms) is unavailable for most countries from our primary sources (Political Handbook of 
the World and the Europa Year Book). We therefore first asked whether the orientation of a party was immediately obvious from its name. If it was not, or if our primary sources disagreed about orientation, we consulted a European website mantained by Agora Telematica (http://www.agora.stm.it/elections/parties.htm) edited by Wilfried Derksen. Its coverage is non-historical, however. Party orientation was also cross-checked against with information in Political Parties of Africa and the Middle East and Politica! Parties of Eastern Europe, Russia, and the Successor States, both published by Longman Current. Affairs series. In the rare cases where conflict emerged among these sources, we used the web site and noted the conflict in the Excel spreadsheet.

The first categorization refers to preferences regarding greater or less state control of the economy - the standard left-right scale. Parties on the right are therefore those with the terms "conservative" or "Christian democratic" in their names, or that are labeled right-wing in our sources. Similarly, we classify parties as left if their names reveal them to be communist, socialist, or social democratic or if the sources label them as left-wing. We classify parties as centrist that are called centrist by our sources or if their position can best be described as centrist (e.g., because the party advocates the strengthening of private enterprise but alsa-supports a redistributive role for government, for example in the form of a tightly knit safety net). Any party that cannot be classified in any of the three categories is categorized as "other". These are frequently parties in non-competitive electoral systems.

The second dimension we consider is "nationalism". A party or the chief executive is coded as nationalist if (i) a party is listed or described as nationalist in our sources, or (ii) a primary component of the party's platform is the creation or defense of a national or ethnic identity. With respect to the latter, parties that fought for independence from a colonial 
power, such as the Indian National Congress, or advocate the restriction of rights of minorities, such as the French National Front Party, are notable examples.

A third dimension coded in the DPI is whether a party is rural or not. A party is classified as rural if either the platform or the constituency is mainly rural. Finland's and Sweden's Center Parties are prominent examples of rural parties. Similarly, a party is classified as regional if either the platform or the constituency pertains mainly to a specific region of the country. Examples include most of the Belgian parties, since separate parties exist in the Wallonian and the Flemish part of the country.

Finally, we classify a party as religious if government policy towards religion or the members of a particular religion are among the party's core issues. We distinguish such parties using, once again, the source characterizations of either the party's platform or constituency. In predominantly Islamic countries, parties are defined as religious if the chief executive or party leader is also a religious leader, as is the case in Iran. The database also captures, among others, religious parties in Israel, the Buddhist Komeito party in Japan and the Hindu-based Bharatiya Janata Party (BJP) in India. With respect to Christian-Democratic parties, if any one of our sources indicated that religious issues were a central part of their party platform, they are.indicated as Christian. Both the Italian and German Christian Democratic parties are therefore coded as having religion as an important element of party orientation. Since religious issues are arguably not the most central or salient concern of party members, this suggests that this variable is somewhat biased towards identifying a religious orientation where none exists. On the other hand, for social policy issues, or on questions such as immigration, the coding is likely to distinguish these parties from others in the respective political systems in ways that are both relevant and useful. 


\section{Tenure, turnover and popular vote sbare of the Chief Executive and the Chief Executive's} Party

A key hindrance to development is the tendency of many political leaders to make opportunistic decisions that entail long run costs to society that far outweigh short-run benefits. The expropriation, directly or via taxation or regulatory policy, of private assets is the most obvious example of such decision making. Leaders with shorter horizons in office are more likely to find such choices to be worthwhile, and there is evidence suggesting that this effect is significant, at least in less democratic countries (Clague, et al., 1996; see also Alesina, et al., 1996). All research that has documented this effect has relied on data on the tenure and turnover of governments (cabinets or prime ministers in parliamentary systems) or presidents. This information is available in this data set, as well, for larger number of countries than previously available. However, the DPI also provides opportunities to circumvent several ambiguities that arise from reliance on existing data.

First, executives whose terms are shortened by constitutional limits on tenure might react differently to limits on their time in office compared to other executives, with similar horizons that are limited in other, perhaps non-constitutional ways. This data set therefore includes variables indicating whether there are constitutional restrictions on executive terms and whether sitting executives can be re-elected.

Second, executives with a stronger hold on power should, all else equal, have a longer horizon than other executives. In particular, one would expect leaders with more popular support, or weak opposition, to have a longer horizon. The strength of the political position of leaders can be taken into account, at least partially, using variables that record the share of votes that presidents received in their last election, and the share of votes of the prime 
minister's or president's party.

Third, one would expect that stronger parties would rein in party members who happen to have shorter horizons. Again, the DPI provides information that allows this to be taken into account: the number of years that the party of the executive has been in office (independent of the particular executive who has represented the party), and how long the party has existed under its current name. Where the party of the executive has been in power longer than the executive, it is more likely that the party restrains executives with short horizons. Similarly, parties that have been in existence for a long period of time should have a longer time horizon than parties that have not. We count the party's existence from the date it adopted its name. Parties incur losses when they change their name, not least of which is a loss of brand name. Frequent name changes indicate either that parties have no brand name or are not well-established institutionally (to the extent that these two things are different).

Finally, existing investigations of the effects of expected tenure or government turnover track only one decision maker in a country, the head of government (president, prime minister or cabinet). Most democratic countries, however, have multiple decision makers. A parliamentary government can fall and be replaced by government with an entirely-new set of coalition parties, or by a new government with substantially the same set of coalition partners. A president can be replaced with, or without, the corresponding replacement of the majority parties in the legislature. Theory would suggest that dramatic changes in government policy, or in the potential for expropriatory behavior by governments, are likely only when all decision makers are replaced. Empirical measures of tenure and turnover have not matched this, however.

The DPI records whether parties are in the government coalition or not, and whether 
the party of the executive controls the lower house (there is no data on upper houses in this data set). With this information, one can calculate which of the main veto gates (legislature, executive) in a system have changed hands in any year. Based on this information, the data set contains two new variables, STABS and STABNS, on government stability that capture the extent of turnover in any one year of a government's key decision makers. They are calculated by dividing the number of exits between year $t$ and $t+1$ by the total number of veto players in year $t$. The variables are therefore on a $0-1$ scale, with zero representing no exits and one representing the exit and replacement of all veto players. Veto players are defined as the president, largest party in the legislature, for a presidential system; and as the prime minister and the parties in the government coalition in a parliamentary system. These variables, are correlated at approximately .87 with simple measures of executive turnover. While not dramatically different, they are different enough to suggest that hypothesis tests invoking instability should be robust to both types of measures.

Along the same lines, measures of tenure length used in current research often refer only to the executive. The DPI has several variables that provide different perspectives on tenure, include the tenure of the veto player who has been in office the longest and the shortest period of time, assuming multiple veto players, as well as the tenure of the political system - how long have executive elections been competitive (at least six on the Executive Index of Electoral Competitiveness) or, if they have not been competitive, how long the executive has been in office.

\section{The Legislature}

The role of the legislature in the political process is influenced not only by constitutional restrictions on the scope of its initiative and veto authority, but also by its 
composition and the relative strength of government and opposition coalitions. Currently, in order to characterize the internal structure of legislators, researchers have had to rely on measures of fractionalization of the legislature: the probability that any two legislators drawn at random would belong to the same party. Greater fragmentation is taken to imply a larger number of actors willing to act independently in the consideration of any given policy change. This variable has proven useful, but it treats as identical highly dissimilar cases. For example, the variable would record the same value for two legislatures: the first, in which a single opposition party controls 49 percent of the seats, 10 government parties share 49 percent of the seats, and a remaining government party controls 2 percent of the seats and a second, in which a single government party controls 49 percent of the seats with a coalition partner that controls 2 percent, while 10 opposition parties share 49 percent of the seats.

The data set introduced here allows for the calculation of the traditional measure of legislative fragmentation. However, our sources also allowed us to identify which parties were inside and outside of the governing coalition. For coalition governments, the sources generally list the party affiliations of cabinet ministers. Otherwise, the country descriptions provided this information. Where the information was not available, for a small number of parties and countries, this is indicated in the DPI. With this information, variables were created to record separately the fragmentation of the government coalition and the opposition. The correlation of the government and opposition fragmentation measures is only 0.267 , suggesting that average fragmentation for the entire legislature is likely to be misleading for many purposes. For example, the number of checks (parties in a government coalition) in parliamentary systems cannot be reliably inferred from fragmentation of the whole legislature. Similarly, in investigations of the relative influence of executives and 
legislatures when legislatures become more fragmented, the relevant issue is the fragmentation of government-allied parties, on which the DPI has information.

\section{Electoral Rules}

The incentives of political decision makers, and their ability to act independently of each other, depends in large measure on the electoral rules under which they operate. Among other effects, electoral rules influence whether candidates have an incentive to pursue individual or party interests; whether small and single-interest parties have an incentive to coalesce or to remain independent; and whether party leaders exercise significant or weak influence on party candidates. Each of these and other, similar electoral characteristics have a bearing on whether legislators are more or less permeable to special interests.

One electoral rule that affects responsiveness to narrow interests is the Mean District Magnitude (MDM). The MDM is defined in the database as the average number of representatives (rounded to the nearest whole number) elected by each electoral district in a country. ${ }^{1}$ Higher values of MDM (combined with proportional voting rules) reduce the incentives of parties to coalesce and allow parties representing exclusively narrow interests the chance to gain a voice in a government coalition. MDM is coded for up to two legislative chamberss (House and Senate), if they have elected members. The MDM varies from one in the United States or the United Kingdom to as many as 153 for the Congo.

A second electoral characteristic that the data set captures is whether the districts of the upper house are states or provinces. This is particularly useful in studies of federalism: the

1 Cox (1997, p. 208), argues that the median district magnitude is superior, conceptually, but data on distribution of seats across constituencies is not available from our sources and Cox also acknowledges that empirically, the distinction has not proven important. 
more closely that the constituencies of national legislators match those of sub-national governmental jurisdictions, the more likely that those sub-national interests will be reinforced in national-level decision making.

Voting rules are a third aspect of electoral rules. The DPI records whether legislators are elected using majority (first past the post) or proportional representation systems. These rules affect candidate incentives to adhere to party positions (as in proportional representation) and to build up personal constituencies at the expense of party positions. If at least some members of the legislature are elected by simple majority vote, the electoral system is coded as "pluralistic." If at least some candidates are elected based on the percentage of votes received by their party, the system is coded as proportional representation (PR). Countries are allowed to (and do) exhibit both systems; in this case, the system that governs the majority of candidates is indicated for each legislative chamber.

Proportional representation systems differ widely according to whether they favor large or small parties or privilege party leaders or individual candidates (see Cox 1997 for a thorough discussion). The data set therefore records if there is a threshold that parties have to overcome in order to gain any seats in the legislature and whether the D'Hondt system, which is less favorable to small parties, is used to calculate the number of seats that each party receives. There is also a variable that records whether the electoral system is closed or open list. A system is classified as closed if voters cannot express preferences within a list - that is, if the position on a party's candidate list combined with the number of votes received by the party is the sole determinant of whether a candidate is elected or not.

Some, albeit scanty information is available on the candidate selection process. Especially in majoritarian settings, this is a crucial dimension along which countries vary in 
the extent of party control of candidates. Systems that use "smoke-filled back rooms" to identify a party's candidates offer party leaders greater influence than those that use party primaries. Where possible, the data set therefore includes a variable that reflects whether selection is of one of the following three types:

1 on a national level, i.e. by national executive, party leader, interest groups or party factions;

2 on a sub-national level, i.e. by subset of constituency party members e.g. on conventions;

3 by primary election, including party primary and primaries using all the votes of a constituency.

The DPI, finally, records the month when presidential/parliamentary elections were held.

\section{Checks and Balances}

A key element in the description of any political system is the number of decision makers whose agreement is necessary before policies can be changed. Numerous decision makers with different policy preferences are likely to respond differently (more incrementally, for example) to reform opportunities than single decision makers. On the other hand, countries with multiple decision makers may offer greater protection from arbitrary government action to individuals and minorities. Interests that are unrepresented by government decision makers when there are few key decision makers may gain representation when the number of decision makers rises.

The DPI significantly extends one existing measure of checks and balances, and introduces new measures and the possibility of constructing others. One existing measure is the Index of Political Cohesion, originally devised and coded by Roubini and Sachs (1989) for a set of 14 OECD countries to study the political and economic origins of high-debt countries. 
They record whether the same or different parties control the executive and legislature in presidential systems, and, in parliamentary systems, whether there is a one, two, or three or more party coalition controlling government, or a minority government. The DPI has information on governing and opposition parties for over 150 countries, allowing the Index of Political Cohesion to be compiled for a much larger sample of countries.

There are significant coding differences for the 14 overlapping countries, however, so that for these common observations there is a correlation of only .53 between the two. For example, we differ from the original coding by Roubini and Sachs of the Index in calling Japan a minority government for particular years, in labeling Finland a parliamentary system, and in coding the CDU and CSU in Germany as two parties rather than one (XXsee annex xx for a complete identification of differences). This has a significant impact on their empirical findings, at least over the ten years that the two versions overlap. Table 2 reports results from Roubini and Sachs, replicated for the years 1975 - 1985, using their original coding of the Index and the coding in the database. ${ }^{2}$ They argue, reasonably, that coalition governments should have greater difficulty responding to the sudden emergence of crisis-driven budget deficits, a common occurrence in this decade.

- They confirm this conjecture in their empirical work, replicated in Column 1, Table 2 for the eleven year period for which the two databases overlap. The IPC coefficient is large, positive and statistically significant. However, using the coding of the Index of Political Cohesion from DPI, we find no such relationship (see Column 2, Table 2). What explains these divergent results? As Table 3 demonstrates, there are several reasons for the differences

2 Our data on unemployment and inflation differ slightly from theirs, but despite this, in our replication using their own coding of $I P C$ we find as they do that $I P C$ has a large and positive association with public debt. 
in their Index of Political Cohesion and the one coded for the DPI.

Table 2: Divided government and government debt

\begin{tabular}{|llll|}
\hline $\begin{array}{l}\text { Dependent variable: } \\
\text { change in public } \\
\text { debt/GDP }\end{array}$ & $\begin{array}{c}\text { Original Index of } \\
\text { Political Cohesion } \\
\text { (IPC) } \\
\text { (Roubini/Sachs) } \\
(1)\end{array}$ & $\begin{array}{c}\text { IPC from } \\
\text { Database of } \\
\text { Political } \\
\text { Institutions } \\
(2)\end{array}$ & $\begin{array}{c}\text { CHECKS1 } \\
\text { from Database } \\
\text { of Political } \\
\text { Institutions } \\
(3)\end{array}$ \\
\hline constant & -0.84 & 0.31 & 0.18 \\
lagged change in & $(0.53)$ & $(0.54)$ & $(0.96)$ \\
public debt $(t-1)$ & 0.867 & 0.84 & 0.84 \\
change in & $(0.09)$ & $(0.09)$ & $(0.09)$ \\
unemployment rate & $(0.11)$ & 0.057 & 0.06 \\
change in debt & -0.20 & $(0.12)$ & $(0.12)$ \\
service costs & $(0.18)$ & -0.15 & -0.17 \\
change in growth & -0.32 & $(0.19)$ & $(0.18)$ \\
rate & $(0.10)$ & -0.27 & -0.32 \\
Japan (0-1) & 2.48 & $(0.12)$ & $(0.11)$ \\
& $(1.55)$ & 0.67 & 0.74 \\
IPC or $C H E C K S 1$ & 0.74 & $(1.47)$ & $(1.62)$ \\
& $(0.30)$ & -0.053 & 0.02 \\
$N$ & 83 & $(0.28)$ & $(0.23)$ \\
Adjusted $R^{2}$ & 0.54 & 79 & 83 \\
\hline
\end{tabular}

Note: This table reproduces the specification from Table 7, column 2, Roubini and Sachs, 1989, for the years 1975 - 85 (years of overlap with our dataset). Standard errors are in parentheses. Debt service costs are the real interest rate less the growth rate, multiplied by lagged debt/GDP. Column 2 excludes four observations (Italy and the US, 1975-76) for which IPC in the DPI is unavailable.

The coding differences noted in Table 2 have two effects. One is to raise the sample mean substantially, from 1.18 to 1.51 . The other is to reduce the dispersion in the DPI measure of IPC among the fourteen countries; the IPC compiled by Roubini and Sachs exhibits a coefficient of variation of 83.5 , while that of DPI is 72.4 . These changes are not surprising. One would expect that fourteen wealthy, democratic OECD countries would exhibit more significant checks on government decision makers that higher values of the IPC imply, and that they would not exhibit large and sustained differences in such a fundamental political variable as the extent of divided government. The effects of divided government are 
likely to be non-linear - with the impact of a second independent decision maker being much greater than the addition of a third, for example - providing one explanation for the insignificant results in column 2, Table 3. Similarly, the reduced dispersion of the IPC in the DPI would also explain the differences in the results across columns 1 and 2 of Table 2.

Table 3: Differences in Coding the Index of Political Cohesiveness: Database of Political Institutions and Roubini and Sachs (1989) (OECD nations, 1975-1985)

\begin{tabular}{|c|c|}
\hline Source of Difference & Observations Affected \\
\hline $\begin{array}{l}\text { DPI counts CDU and CSU as } 2 \text { parties; RS89 } \\
\text { counts them as } 1 .\end{array}$ & $\begin{array}{l}\text { Federal Republic of Germany, } \\
\text { 1983-1985 }\end{array}$ \\
\hline $\begin{array}{l}\text { DPI indicates 2-party government; RS89 } \\
\text { indicates a 1-party government. }\end{array}$ & $\begin{array}{l}\text { United Kingdom, } 1978 \\
\text { Norway, } 1975-1980 \\
\text { Sweden, } 1975\end{array}$ \\
\hline $\begin{array}{l}\text { DPI indicates a minority government; RS } 89 \\
\text { indicates a majority government of one party } \\
\text { or a majority coalition. }\end{array}$ & $\begin{array}{l}\text { Belgium 1982-1985 } \\
\text { Denmark 1978, 1984-1985 } \\
\text { Japan 1977-1980, 1984-1985 } \\
\text { Norway 1985 } \\
\text { Sweden 1983-1985 } \\
\text { UK 1977, } 1979\end{array}$ \\
\hline $\begin{array}{l}\text { DPI indicates a minority government, RS89 } \\
\text { indicates a majority government of one party } \\
\text { or a majority coalition. It is also possible that } \\
\text { language- based "wings" of parties are treated } \\
\text { differently - DPI often counts them as separate } \\
\text { parties. }\end{array}$ & Belgium, 1976-1977 \\
\hline $\begin{array}{l}\text { For each year, DPI records the situation as of } \\
\text { January 1; RS89 seem to use a different } \\
\text { convention. }\end{array}$ & $\begin{array}{l}\text { Denmark, } 1981 \\
\text { Ireland, 1981 } \\
\text { Norway, 1981-1982 } \\
\text { Sweden, 1976, 1978-1979, } 1981\end{array}$ \\
\hline $\begin{array}{l}\text { Possible that language-based "wings" of parties } \\
\text { are treated differently - DPI often counts them } \\
\text { as multiple parties. }\end{array}$ & $\begin{array}{l}\text { Netherlands, } 1978-1985 \\
\text { Belgium, } 1981\end{array}$ \\
\hline $\begin{array}{l}\text { DPI classifies them as parliamentary; RS89 } \\
\text { classifies as presidential. }\end{array}$ & $\begin{array}{l}\text { Finland, } 1975-1985 \\
\text { France, } 1975-1985\end{array}$ \\
\hline
\end{tabular}


One can examine the robustness of the results in column 2 by substituting for IPC a measure of the number of independent decision makers in a government. The underlying logic of the Roubini and Sachs argument suggests that such a measure, too, should be correlated with the difficulty of responding to fiscal crisis. One such measure in the DPI is the variable CHECKS1, a measure of checks and balances that is explained below. Results using CHECKS1 in place of IPC are displayed in Column 3, Table 2, and again demonstrate no significant relationship between the number of decision makers and response to fiscal crisis in this small and relatively homogeneous sample of countries.

Because of the small and relatively homogeneous number of countries considered, the results in columns 2 and 3 of course do not reject the Roubini/Sachs conjecture - divided governments have greater difficulties in agreeing to a response to crisis. They only suggest that as we advance in our attempts to make cross-country institutional characterizations of polities, legitimate distinctions will arise among superficially similar concepts. On the one hand, these distinctions need to be subjected to scrutiny; on the other hand, if they are reasonable, they need to be used to test the robustness of empirical claims in political economy. Where robustness is weak, this likely implies new opportunities for research: why do some measures of checks and balances, following one set of criteria, lead to results that are not replicable using other reasonable measures of checks and balances, capturing different institutional dimensions?

The Index of Political Cohesion does not distinguish countries according to the effectiveness of electoral checks on government decision makers. This is a particularly relevant concern when expanding the index to a set of countries outside of the OECD. When 
electoral checks are few, perhaps because of laws limiting political competition, executive control of the legislative apparatus is usually strong. Legislative seats depend on party nomination, which in turn is usually vested in the executive in such countries. The Index also does not take into account electoral rules that influence party control over members, an issue even in OECD countries. Where party control is weak and the same party controls both the legislative and executive branches of a presidential government, this index would understate the level of checks and balances by coding the country as not having a divided government.

To adjust for these circumstances, the DPI includes two new variables, CHECKS1 and CHECKS2. These variables count the number of veto players in a political system, adjusting for whether these veto players are independent of each other, as determined by the level of electoral competitiveness in a system, their respective party affiliations, and the electoral rules. Both variables take into account the Legislative Index of Electoral Competitiveness. If the index is less than four, the two measures are set equal to one since, regardless of the formal constitutional arrangements in a system, where legislative elections are uncompetitive, constitutional checks on officials are unlikely to be binding.

For values of the electoral competitiveness index of four or more, the variable CHEGKS1 is increased by the number of veto players in the system. ${ }^{3}$ In presidential systems, it is increased by one for the president and one for each legislative chamber. However, if elections are conducted under closed list rules (closed list equals one) and the president's party is the largest government party in a particular chamber, then it is assumed that the president exercises substantial control over the chamber and it is not counted as a check. For

3 The values of CHECKS1 and CHECKS2 are nearly invariant to the use of the Executive or Legislative Index of Electoral Competitiveness. 
parliamentary systems, CHECKS1 is increased by one for the prime minister and the number of parties in the government coalition, including the prime minister's own party. If the system is closed list, however, and the prime minister's party is the largest in the government coalition, then this sum is reduced by one. Relative to the Index of Political Cohesion, then, CHECKS1 allows a legislative chamber to exercise veto power even if the same party controls both the chamber and the executive branch.

Keefer and Stasavage (1999) use CHECKS1 to demonstrate that the delegation of monetary policy to a central bank has a significant dampening effect on inflation only in the presence of checks and balances. Keefer (1999) finds that the determinants of banking crises are substantially different in countries that exhibit high values of CHECKS1 compared to those countries that exhibit lower values.

The variable CHECKS1 can also be used to fuel the debate about whether presidential or parliamentary forms of government are likely to result in "decisive" decision making. Some (see Stepan and Skach, 1993) argue that presidential governments are more likely to give rise to gridlock, since neither the legislature nor the executive has an incentive to give way in policy debates because they are independently selected. It is not clear, however, which is more likely: that an independent legislature would veto the proposals of an executive, or that members of a government coalition in a parliamentary system would veto the same proposal emanating from another member of the coalition. The average CHECKS1 variable for all countries that score either six or seven on the Legislative Index of Electoral Competitiveness is actually much higher for parliamentary systems (3.57) than for presidential systems (approximately 1.96). While legislative and executive interests are rarely unified in presidential systems, governments in parliamentary systems are even less so. However, it 
remains unclear whether bargaining among multiple coalition partners in parliamentary systems regarding particular proposals is less costly than bargaining between only two veto players in presidential systems. The DPI data set, however, provides one tool for advancing research on this question.

The extent to which one political decision maker might act as a check on another depends in part on the similarity of their policy preferences. Government decision makers are more likely to exercise strong veto power if their policy preferences are closer to those of the opposition and more distant from the preferences of other government decision makers. Such a decision maker would be more willing to leave the government and join the opposition than decision makers whose views were far from the opposition. To take into account the policy orientation of parties, a second checks and balances variable, CHECKS2, was therefore compiled and introduced into the data set. CHECKS2 is therefore the same as CHECKS1, but is augmented by one for every veto player (defined as the largest government party in the legislative chamber in presidential systems, and all coalition members in parliamentary systems) whose orientation (left, right or center) is closer to the opposition's orientation than to the average of the rest of the government. The opposition's orientation is given by the orientation of the largest opposition party.

These new measures of checks and balances offer considerable additional information about polities. Their correlation with the coding of Index of Political Cohesion in the database is less than 0.60 . This suggests that theoretical priors about the number of veto players in government can make a significant difference for empirical work, reinforcing the need for diverse data sets and variables. 


\section{Federalism}

Sub-national political structure affects national level policy making in numerous ways. First, sub-national units may have veto power over national level policy decisions. Second, they may exert pressure for greater, or at least different levels of redistribution than would otherwise be the case. Third, their existence may affect the cohesiveness of national parties, which struggle for positions in both sub-national and national jurisdictions, although the distribution of voter preferences in the two could be quite distinct.

There are several variables in the DPI to capture the extent of federalism in a country's political structure. The first is whether there are contiguous autonomous regions in a country. An autonomous region is recorded if a source explicitly mentions a region, area or district that is autonomous or self-governing. We required that autonomous regions be constitutionally designated as "autonomous", "independent" or "special".

A second dimension of information on sub-national governments is whether state/provincial governments are locally elected. This is zero if neither the local executive nor the local legislature are directly elected by the local population that they govern; one if either is directly elected and the other is indirectly elected (e.g., by councils at subsidiary levels of government) or appointed; and two if they are both directly and locally elected. If there are multiple levels of sub-national government, we consider the highest level as the "state/province" level. We also investigated, with limited success, whether municipal governments were locally elected. This was coded the same as the state/provincial government. If there were multiple levels of sub-national government, we considered the lowest level as the "municipal" level.

The third dimension on which we attempted to collect information is the jurisdiction 
of local governments. We asked whether the states or provinces had authority over taxing, spending, or legislating. The variable is coded as one if our sources report authority over any of these areas.

\section{Sources and Data Collection}

There were two main sources of data for this project, each used for a different time period. For the period 1975-1984, Europa Year Book was consulted For the period 1985-1995, the Political Handbook of the World, edited by Arthur Banks, was used. However, Europa was also used in this second time period to plug topical gaps in coverage, mostly for electoral rule and constitutional framework variables.

There were several reasons for dividing our study between two sources. First, prior to 1985, the Political Handbook of the World was published every 2-4 years and lacked detailed, year-by-year observations. This factor recommended Europa for the first time period. In the period 1985-1995, the two books provided complementary information. Europa has better data on the number of seats held by parties, the constitutional framework and electoral rules over this period, while the Handbook offers more detailed information on the ideological orientation of the parties and recent political history. Therefore, both sources were used, with an emphasis on the Handbook.

The consistency of data between these two time periods was extensively checked. The collection system helped ensure that discrepancies would be identified and discussed, since different people were responsible for coding different time periods. In the event of discontinuities in the $1984-85$ period, the coders' approaches were discussed among a wider group, including most of the authors of this paper, to determine which was more appropriate, and the country-variable was re-coded accordingly. Most of these discontinuities involved 
time-sensitive variables (how long in office, in majority, etc.); electoral rule variables (closed list, plurality/PR); and the ideological orientation of parties. They were resolved largely by establishing and refining the conventions of data collection, such as when a ruler was credited with taking office (in former colonies, upon internal self-government rather than independence) or what exactly constituted an electoral rule (whatever rule governs the majority of seats). There were, besides, extensive consultations on resolution of ambiguities. The results of these discussions are all reflected either in the documentation sheet, in the form of rules that were followed for coding, or in the notes embedded in the corresponding cells in the Excel spreadsheet.

Electoral rules were more difficult to capture than other institutional variables, and were often not available in the handbooks. For the later period (1985-1995) we took most of our data from the website of the International Parliamentary Union, which reports rules for 1998. When this data matched the institutions described in $1975-1984$, we assumed that no changes had been made and filled in the intervening years. In the event that a system changed and then switched back, this introduces errors. Since this assumption was made only when institutions from 1984 matched those in 1998, these cases are limited to very stable democracies. In the case where IPU-1998 did not match earlier data, the IPU data was only inputted for 1995, and blanks were left for remaining years.

There were a number of alternative sources of data that could have been used. Prominent among these is the Statesman's Year Book edited currently by Brian Hunter. This is a valuable source, but we rejected it in favor of the above sources for several reasons (recalling that the addition of a single source to the compilation process implied at least four personmonths of additional work). First, although Statesman's level of detail is excellent in Europe 
and developed nations, its coverage of developing nations is less detailed than in our preferred sources. The number of seats won by parties is more often omitted, as is the identification of parties as affiliated with or opposed to the government. Details on the electoral systems are also more often absent, as are vote percentages for presidential systems. Our sources provided information on seats, parties, and election results more consistently in developing nations. The reporting in Statesman's also lagged events by a few years, especially in developing nations or nations emerging from Communism. For example, election results in countries such as Kazakhstan or Kyrgisztan are not covered until 1995, compared to 1992 in our preferred sources. Finally, Statesman's rarely provided lists or descriptions of active parties.

Another possible source for this database is Keesing's Record Of World Events. This source was rejected because it was primarily focused on news rather than permanent institutions; and because it is organized by month, creating significant compilation costs since relevant data would have to be scoured from every month's report. Various other sources (CIA Handbook of the Nations, OECD Political Data Handbook edited by Lane, et al., the Year Book of World Affairs, produced by the London Institute of World Affairs) were rejected for reasons of coverage and focus.

- Despite the use of comprehensive sources and detailed cross-checking procedures, there are several variables which need to be treated with some caution because of the fundamental limitations of cross-country sources such as those upon which we relied. Party orientation is one of these, since we were unable to rely on systematic listings of party platforms or legislative positions. However, since our first-cut source (the party name/description in the handbooks) and our default source (the Agora website) disagreed infrequently, we believe these variables can be used with confidence. 
Information scarcity hindered the coding of all of the federalism variables. Thirtyeight percent of the observations are coded for the sub-national authority variable, and 42 percent of the municipal election variables. The remainder are blank.

The indices of electoral competitiveness were coded according to a carefully established set of conventions, all of which are described in the documentation. Nevertheless, there are many cases that defied simple categorization (all noted either with notes in the Excel spreadsheet, or in the documentation). When executives were elected by a body other than the overall populace, we apply the categorization to that electing body (often the legislature, but sometimes an electoral college) and impute its score to the executive. This results in military governments of Brazil, Thailand, and South Korea receiving unusually high scores (57), since they did not "take" power, but instead followed formal institutional procedures that involved selection by an elected legislature. Similarly, even if a powerful executive rigged the elections (which is recorded elsewhere), the country could still be scored a six or seven. While the formal procedures are likely to understate the level of military control of the process, and overstate the level of electoral competitiveness, we preferred to preserve the conventions in these cases.

-Special rules were devised to handle deviations from constitutional procedures. If an executive or legislature illegally suspends or ignores elections, the suspending entity is scored with a two starting in the year after the event. If unelected dictators subsequently hold a plebiscite to confirm their claim to office, their score is raised from two to three, but only if the plebiscite is binding. Dynastic rulers in Arab countries, who inherit power, or otherwise obtain it through obscure intra-family negotiations, are given the same "two" earned by military officers who seize power in a coup. 


\section{The DPI compared to other databases}

The DPI seeks to add to existing knowledge on political institutions, and to gather into one source information that had previously been scattered. Therefore, it is reasonable to ask how this database compares to other political databases, in terms of detail, coverage, and focus. Comparisons to two illustrate the potential contribution of the DPI to future empirical research in cross-country political economy. One of these is the Polity III database compiled by Gurr, et al. (1998), and the other are the objective assessments of government checks and balances created by Henisz (1997).

Polity III. Gurr, Jaggers, and Moore (1998) have compiled Polity III, covering a time period stretching from 1800 to 1994 . Polity III covers 156 nations - all those with populations above 500,000 - and 20 areas that were later amalgamated into a single nation-state (Saxony, Hesse, etc. into Germany; Lombardy, Tuscany, etc. into Italy). By comparison, our database covers all sovereign nations with populations above 100,000 - in all, 177 countries, for the years $1975-1995$.

Polity III includes numerous subjective indicators of the political and institutional environment in countries. However, these tend to be highly aggregated. For example, subjective measures of regulation, competition, and openness in executive recruitment incorporate information about the elections or their absence; fraud; coups; scope of participation in the selection of the executive; military involvement; the number of competing parties; and other relevant factors. The weights assigned to these different characteristics, all of which are appropriate to consider, are not clear, however. The Polity III variables "regulation" and "competitiveness" of participation, like most of the Polity III variables, exhibit similar highly aggregated characteristics. Implicit in their codings are evaluations of 
political violence and fraud; constituencies of parties; legality of parties; and the endurance of parties over time. Using this aggregate level of data organization, many qualities of the political system can be captured by a very few variables, and the net effect of formal and informal (harder to observe and codify) influences can be summarized. The disadvantage of this information is that those seeking specific details on the electoral system will find this information inextricably entangled with the other measures comprising the variable.

By comparison, the DPI uses variables that reflect only one dimension. For example, many variables are dummies, focusing on questions such as "is the closed list system used?", "is the chief executive in the military?", or "was there electoral fraud?". Examples of non-dummy variables include the seats, ideological orientation, and government/opposition affiliation of political parties; details on the level of federalism; the elapsed time in office of the chief executive; and the timing of elections. This database thus presents data at a disaggregated level. With some exceptions, the DPI generally avoids the use of variables that wrap several different measures into one number. The creation of such variables is left to the user. The exceptions to this are the Indices of Electoral Competitiveness and the CHECKS variables. The electoral competitiveness variables take into account rules governing whether parties can run andactual outcomes - whether parties do run and win seats. The CHECKS variables draw on several variables within the database to construct an index of checks and balances in the political system. While our variables therefore do not necessarily reflect the informal constraints on electoral competition or executive authority, they allow researchers to identify the extent of formal constitutional control on political decision makers.

In addition to methdological differences in the two databases (subjective and aggregated, but evaluating both formal and informal conditions in a country, compared to 
objective and disaggregated), there also differences in the types of variables included. Our database has no information on "collective executives", such as military juntas; nor information on the scope of government action or regulation in the polity; nor on the creation, destruction or nature of regime change in polities. On the other hand, the DPI permits users to track more frequent and micro-level changes in regimes, such as the composition of the legislature, changes in executive, or changes in the electoral competitiveness indices. It also features several dummy variables representing details of the electoral system and much more detail on parties in the system.

Political constraints. Henisz (1997) presents another valuable source of information on political institutions, in particular the data necessary to create a measure of checks and balances. His series addresses some key issues, such as the number of chambers in a legislature, the degree of federalism, Supreme Court turnover, factionalization of the legislature, and the relative influence of different parties among the executive, legislature, and judicial branches. From this information, he formulates a measure of political constraints that is analagous to, but different in construction from, the CHECKS variables reported here. The Henisz data has a longer time-series, but substantially fewer variables (e.g., with regard to government or opposition parties, party orientation, electoral rules, the different federalism indicators, etc.).

Keefer and Stasavage (1999) report empirical results using CHECKS1, from the DPI, political constraints from Henisz, and Executive Constraints, a subjective variable from Polity III. The key conclusions are generally robust to which variable is used (central bank independence matters more in the presence of checks and balances). However, these variables are not so closely correlated that one can assume robustness. 


\section{Conclusion}

This database is the product of an effort to bring systematic, cross-country information on political institutions within easy reach of researchers investigating comparative political economy. We have found no other source of information that provides as much objective data on these issues. Others, including some of the authors of this paper, have previously used in other work the data sources relied upon to construct this data these variables (see Clague, et al., 1996, or Durham, 1999). However, we have found no case where all of the information has been compiled, and we have identified many variables that have never been collected. Examples of these are the variables identifying party orientation, party affiliation with the government or opposition, the military affiliation of the executive or minister of defense.

The early part of the paper outlined a subset of the questions that the Database of Political Institutions can potentially illuminate. They stretch across political science and economics, ranging from the determinants of democratic consolidation, the political conditions for economic reform, and the political and institutional roots of corruption, to the appropriate and institutionally-sensitive design of economic policy recommendations. To enhance the availability of the DPI for these purposes, it will be placed on several websites, particularly the political economy website of Harvard University and the website of the World Bank's Development Economics Data Group. 


\section{Annex 1: List of Variables}

The Database on Political Institutions (DPI) is a large new cross-country database of political institutions that covers 177 countries over 21 years, 1975 - 1995. This database was prepared by Thorsten Beck, George Clarke, Robert Cull, Alberto Groff, Philip Keefer, and Patrick Walsh of the Development Research Group of the World Bank. When using this database, please cite the current paper.

\section{Country Code COUNTRYC}

\section{General Variables}

International Financial Statistics code IFS

Year YEAR

\section{Chief Executive Variables}

Direct Presidential (0); strong president elected by assembly (1); Parliamentary (2) SYSTEM

How many years in office YRSOFFC

Is there a finite term in office? ( 1 if yes, $O$ if no) FINITTRM

Years left in curent term YRCURNT

If there are formal restraints on his term (NA if not), can he serve multiple terms? MULTPL?

Is Chief Executive a military officer? MILITARY

Is defense minister a military officer? DEFMIN

President got what $\%$ of votes in the 1st/only round? PERCENT1

President got what \% of votes in the final round? PERCENTL

Party of chief executive has been how long in office PRTYIN

\section{Chief Executive's Party}

Name of party, if any EXECME

Right (R); Left (L); Center (C); Not applicable (0) EXECRLC

Nationalist ( 1 if yes) EXECNAT

Rural (1 if yes) EXECRURI

Regional (1 if yes) EXECREG

Religious (1 not specified, CH:Christian, CA: Catholic, IS: Islamic, HD: Hindu, BD: Buddhist, JW: Jewish, O: otherwise) EXECREL

Time since formation under this name EXECAGE

Does party of executive control all relevant houses? ALLHOUSE

In systems with both non-ceremonial PM and President, what is the party affiliation of the one not called Chief Executive? NONCHIEF 
Government fractionalization (chance that two random draws will produce legislators from different parties). GOVFRAC

\# of Govt. Seats NUMGOV

Largest Government Party

Name 1GOVME

Seats 1GOVSEAT

Right (R); Left (L); Center (C); Not applicable (0) 1GOVRLC

Nationalist (1 if yes) 1GOVNAT

Rural ( 1 if yes) 1GOVRURL

Regional ( 1 if yes) 1GOVREG

Religious (1 not specified, CH:Christian, CA: Catholic, IS: Islamic, HD: Hindu, BD: Buddhist, JW: Jewish, O: otherwise) 1GOVREL

Time since formation under this name 1GOVAGE

\section{2nd Largest Government Party}

Name 2GOVME

\section{Seats 2GOVSEAT}

Right (R); Left (L); Center (C); Not applicable (0) 2GOVRLC

Nationalist (1 if yes) 2GOVNAT

Rural ( 1 if yes) 2GOVRURL

Regional ( 1 if yes) 2GOVREG

Religious (1 not specified, CH:Christian, CA: Catholic, IS: Islamic, HD: Hindu, BD: Buddhist, JW: Jewish, O: otherwise) 2GOVREL

Time since formation under this name 2GOVAGE

\section{3rd Largest Government Party}

\section{Name 3GOVME}

\section{Seats 3GOVSEAT}

- Right (R); Left (L); Center (C); Not applicable (0) 3GOVRL.C

Nationalist ( 1 if yes) 3GOVNAT

Rural ( 1 if yes) 3GOVRURI

Regional ( 1 if yes) 3GOVREG

Religious (1 not specified, CH:Christian, CA: Catholic, IS: Islamic, HD: Hindu, BD: Buddhist, JW: Jewish, O: otherwise) 3GOVREL

Time since formation under this name 3GOVAGE

Number of other government parties GOVOTH

Number of other government party Seats GOVOTHST

Herfindahl Index for Opposition HERFOPP 
Opposition fractionalization (chance that two random draws will produce legislators from different parties). OPPFRAC

\section{\# of Opp. Seats NUMOPP}

\section{Largest Opposition Party}

Name Largest Opposition Party 1OPPME

Seats Largest Opposition Party 1OPPSEAT

Right (R); Left (L); Center (C); Not applicable (0) Largest Opposition Party 1OPPRLC

Nationalist ( 1 if yes) 1OPPNAT

Rural ( 1 if yes) 1OPPRURL

Regional (1 if yes) 1OPPREG

Religious (1 not specified, CH:Christian, CA: Catholic, IS: Islamic, HD: Hindu, BD: Buddhist, JW: Jewish, O: otherwise) 1OPPREL

Time since formation under this name 1OPPAGE

\section{2nd Largest Opposition Party}

Name 2nd 2OPPME

Seats 2nd 2OPPSEAT

$3^{\text {rd }}$ Largest Opposition Party

Name 3rd 3OPPME

Seats 3rd 3OPPSEAT

Number of other opposition parties OPPOTH

Number of other opposition party seats OPPOTHST

Number of Parties non-aligned/allegiance unknown ULPRTY

Seats non-aligned/allegiance unknown NUMUL

Herfindahl Index Total HERFTOT

Total fractionalization (chance that two random draws will produce legislators from different parties) FRAC

Does one-opp. party have majority in House OPPMAJH

Does one opp. party have majority in Senate OPPMAJS

\section{Details on Legislature}

When were legislative elections held (number records month, 13 indicates unknown month) DATELEG

When were executive elections held (number records month, 13 indicates unknown month) DATEEXEC

Majority (number of government seats divided by total seats) MAJ

Average Age of Parties PARTYAGE

Is there a legislative election? ( 1 " if yes) LEGELEC

Is there an executive election? ( 1 ” if yes) EXELEC

Is executive party special interest? EXECSPEC 
Is 1st gov. party special interest? GOVSPEC

Are any coalition parties special interest? COALSPEC

Legislative Index of Political Competitiveness LIEC

\section{Electoral Rules}

Executive Index of Political Competitiveness EIEC

mean district magnitude (House) MDMH

mean district magnitude (Senate) MDMS

Number of senate/ (number of house + number of senate) $\mathrm{S} / \mathrm{S}+\mathrm{H}$

Plurality? ( 1 if yes, $O$ if no) PLURALTY

Proportional Representation? ( 1 if yes, 0 if no) PR

If Plurality and Proportional Representation which governs the majority/all of the House seats? (1 if Plurality, $O$ if Proportional) HOUSESYS

If Plurality and Proportional Representation which governs the majority/all of the Senate seats? (1 if Plurality,

$O$ if Proportional) SENSYS

What is the vote threshold for representation? THRESH

Is the D'Hondt system used? ( 1 if yes, 0 if no) DHONDT

Are closed lists used? ( 1 if yes, $O$ if no) $\mathrm{CL}$

Candidate selection: national(1), sub-national(2), primary (3) SELECT

Were vote fraud or candidate intimidation serious enough to affect the outcome of elections? FRAUD

\section{Longest tenure of a veto player TENLONG}

\section{Stability and Checks \&: Balances}

Shortest tenure of a veto player TENSHORT

Tenure of system of government if democratic; tenure of chief executive otherwise TENSYS

Index of Political Cohesion (based on Roubini, Sachs 1989) IPCOH

Number of veto players CHECKS1

Checksz $=$ Check1, +1 for each veto player whose orientation is closer to opp than gov CHECKS2

Maximum difference of orientation among Govt. parties (0-2) POLARIZ

\% veto players dropping from Govt., assume Senate changes STABS

$\%$ veto players dropping from Govt., assume Senate doesn't change STABNS

Are there autonomous regions? AUTON

\section{Federalism}

Are the municipal governments locally elected? MUNI

Are the state/ province governments locally elected? STATE

Do Sub-national govts. have extensive taxing, spending or regulatory authority? AUTHOR

Are the constituencies of the senators the states/provinces? STCONST 


\section{References}

Agora Telematica website of political parties. Wilfried Dierksen, editor. (www.agora.stm.it/elections/parties.htm.)

Alesina, Alberto, Sule Ozler, Nouriel Roubini, and Philip Swagel (1996). "Political Instability and Economic Growth." Joumal of Economic Growth 1 (June).

Banks, Arthur S. The Political Handbook of the World, 1986-1996. CSA Publications. Binghampton, 1986-1996.

Clague, Christopher, Philip Keefer, Stephen Knack and Mancur Olson (1996). “Property and Contract Rights under Democracy and Dictatorship." The Journal of Economic Growth 1:2, 243-276 (June).

Collier, Paul and Anke Hoeffler (1999). "Justice-seeking and loot-seeking in civil war." Working paper, Development Research Group, The World Bank.

Cox, Gary W. (1997). Making Votes Count: Strategic Coordination in the World's Electoral Systems. New York: Cambridge.

and Mathew D. McCubbins (forthcoming). "The Institutional Determinants of Economic Policy Outcomes," in Structure and Policy in Presidential Democracies, Stephan Haggard and Mathew D. McCubbins, eds.

Dixit, Avinash and John Londregan (1996). "The Determinants of Success of Special Interests in Redistributive Politics." The Journal of Politics 58:4, 1132-55.

Durham, J. Benson (1999). "Economic Growth and Political Regimes." Journal of Economic Growth 4, 81 - 111 (March).

The Europa Year Book, Vols. 1 \& 2, 1977-1984, 1990-1994. Europa Publications Ltd. London, 1977-1984, 1990-1994.

Ferree, Karen E. and Smita Singh (1999). "Institutional Change and Economic Performance in Africa, 1970-1995." Paper presented at the 1999 meetings of the American Political

- Science Association, Atlanta, Georgia.

Gurr, Ted Robert, Keith Jaggers and Will H. Moore (1998). Polity III Codebook. Center for Comparative Politics, Department of Political Science, University of Colorado, Boulder. Polity III available through the Inter-University Consortium for Political and Social Research.

Heinisz, Witold (1997). "The Institutional Environment for Growth." Mimeo, The Wharton School. 
Hunter, Brian, current editor (issues back to 1864). The Statesman's year-book [ Statistical and bistorical annual of the states of the world for the year. J. New York: St. Martin's Press,

International Parliamentary Union, PARLINE database website. (www.ipu.org/parline-e/parlinesearch.asp)

Keefer, Philip (1999). "Political institutions and crisis: The effects of political checks and balances on the dynamics of financial sector distress." Paper prepared for the meetings of the Western Economics Association, July 1999.

and Stephen Knack (1997). "Why don't poor countries catch up? A cross-national test of an institutional explanation." Economic Inquiry 35:3, 590-602 (July).

and David Stasavage (1999). "Bureaucratic Delegation and Political Institutions: When are Independent Central Banks Irrelevant?" Mimeo, The World Bank (November).

Keesing's record of world events (various years). London : Longman, (weekly).

Lane, Jan-Erik, David H. McKay and Kenneth Newton (various issues). Political data handbook: $O E C D$ countries. New York : Oxford University Press.

Laver, Michael and Kenneth Shepsle (1996). Making and Breaking Governments. New York: Cambridge University Press.

London Institute of World Affairs (1947 - 84). The year book of world affairs. London : Stevens.

North, Douglass and Barry Weingast (1989). "Constitutions and Commitment: The Evolution of Institutions Governing Public Choice in Seventeenth Century England." Journal of Economic History 49:4, 808-32 (December)

Political Parties of Africa and the Middle East: a Reference Guide. Longman Current Affairs Series. Detroit, 1993.

Politicat Parties of Eastern Europe, Russia, and the Successor States: a Reference Guide: Longman Current Affairs Series. Harlow, UK, 1994.

Pritchett, Lant and Jonah Gelbach (1997). "More for the Poor is Less for the Poor: The Politics of Targeting.” The World Bank, Policy Research Working Paper, No. 1799.

Rasmusen, Eric and Mark J. Ramseyer (1994). "Cheap bribes and the corruption ban: a coordination game among rational legislators." Public Choice 78:305-27 (March).

Roubini, Nouriel and Jeffrey Sachs (1989). "Political and Economic Determinants of Budget Deficits in the Industrial Democracies." European Economic Reviewe 33, 903-938.

Schady, Norbert (1998). "Seeking Votes: The Political Economy of Expenditures by the 
Peruvian Social Fund: (FONCODES), 1991-95.” Policy Research Working Paper 2166, The World Bank.

Shugart, Mathew Soberg (1995). "The Electoral Cycle and Institutional Sources of Divided Presidential Government." American Political Science Review 89:2, 327 - 343 (June). and John Carey (1992). Presidents and Assemblies: Constitutional Design and Electoral Dynamics. New York: Cambridge University Press.

Stepan, Alfred and Cindy Skach (1993). "Constitutional Frameworks and Democratic Consolidation: Parliamentarism versus Presidentialism.” World Politics 46, 1-22 (October).

United States Central Intelligence Agency, Directorate of Intelligence (various issues). Handbook of the nations : a brief guide to the economy, government, land, demographics, communications, and national defense establishment of each of 223 nations and other political entities. Detroit : Gale, 1987.

Weingast, Barry (1998). "Political Stability and Civil War: Institutions, Commitment, and American Democracy." In Analytic Narratives, Robert Bates, Avner Greif, Margaret Levi, Jean-Laurent Rosenthal, and Barry R. Weingast, eds. (Princeton: Princeton University Press). 



\section{Policy Research Working Paper Series}

\begin{tabular}{|c|c|c|c|c|}
\hline & Title & Author & Date & $\begin{array}{l}\text { Contact } \\
\text { for paper }\end{array}$ \\
\hline WPS2265 & $\begin{array}{l}\text { The Political Economy of Distress } \\
\text { in East Asian Financial institutions }\end{array}$ & $\begin{array}{l}\text { Paola Bongini } \\
\text { Stijn Claessens } \\
\text { Giovanni Ferri }\end{array}$ & January 2000 & $\begin{array}{l}\text { R. Vo } \\
33722\end{array}$ \\
\hline WPS2266 & $\begin{array}{l}\text { The Impact of Adult Deaths on } \\
\text { Children's Health in Northwestern } \\
\text { Tanzania }\end{array}$ & $\begin{array}{l}\text { Martha Ainsworth } \\
\text { Innocent Semail }\end{array}$ & January 2000 & $\begin{array}{l}\text { S. Failon } \\
38009\end{array}$ \\
\hline WPS2267 & $\begin{array}{l}\text { Do High Interest Rates Defend } \\
\text { Currencies during Speculative Attacks }\end{array}$ & Aart Kraay & January 2000 & $\begin{array}{l}\text { R. Bonfield } \\
31248\end{array}$ \\
\hline WPS2268 & $\begin{array}{l}\text { The Structure of Social Disparities } \\
\text { In Education: Gender and Wealth }\end{array}$ & Deon Filmer & January 2000 & $\begin{array}{l}\text { S. Fallon } \\
38009\end{array}$ \\
\hline WPS2269 & $\begin{array}{l}\text { Context is Everything: Measuring } \\
\text { Institutional Change in Transition } \\
\text { Economies }\end{array}$ & Nauro F. Campos & January 2000 & $\begin{array}{l}\text { J. Victor } \\
36549\end{array}$ \\
\hline WPS2270 & $\begin{array}{l}\text { The Optimal Income Tax When } \\
\text { Poverty Is a Public "Bad" }\end{array}$ & Waly Wane & January 2000 & $\begin{array}{l}\text { H. Sladovich } \\
37698\end{array}$ \\
\hline WPS2271 & Corporate Risk around the World & $\begin{array}{l}\text { Stijn Claessens } \\
\text { Simeon Djankov } \\
\text { Tatiana Nenova }\end{array}$ & January 2000 & $\begin{array}{l}\text { R. Vo } \\
33722\end{array}$ \\
\hline WPS2272 & $\begin{array}{l}\text { Ownership versus Environment: } \\
\text { Disentangling the Sources of Public } \\
\text { Sector Inefficiency }\end{array}$ & $\begin{array}{l}\text { Ann P. Bartel } \\
\text { Ann E. Harrison }\end{array}$ & January 2000 & $\begin{array}{l}\text { S. Fallon } \\
38009\end{array}$ \\
\hline WPS2273 & $\begin{array}{l}\text { The Value of Preventing Malaria } \\
\text { In Tembien, Ethiopia }\end{array}$ & $\begin{array}{l}\text { Maureen L. Cropper } \\
\text { Mitiku Haile } \\
\text { Julian A. Lampietti } \\
\text { Christine Poulos } \\
\text { Dale Whittington }\end{array}$ & January 2000 & $\begin{array}{l}\text { T. Tourougui } \\
87431\end{array}$ \\
\hline WPS2274 & $\begin{array}{l}\text { How Access to Urban Potable Water } \\
\text { and Sewerage Connections Affects } \\
\text { Child Mortality }\end{array}$ & Anqing Shi & January 2000 & $\begin{array}{l}\text { P. Sintim-Aboagye } \\
37644\end{array}$ \\
\hline WPS2275 & $\begin{array}{l}\text { Who Gained from Vietnam's Boom } \\
\text { In the 1990s? An Analysis of Poverty } \\
\text { An Analysis of Poverty and } \\
\text { Inequality Trends }\end{array}$ & $\begin{array}{l}\text { Paul Glewwe } \\
\text { Michele Gragnolati } \\
\text { Hassan Zaman }\end{array}$ & January 2000 & $\begin{array}{l}\text { P. Sader } \\
33902\end{array}$ \\
\hline WPS2276 & $\begin{array}{l}\text { Evaluating the Case for Export } \\
\text { Subsidies }\end{array}$ & Arvind Panagariya & January 2000 & $\begin{array}{l}\text { L. Tabada } \\
36896\end{array}$ \\
\hline
\end{tabular}




\section{Policy Research Working Paper Series}

Title

WPS2277 Det

Bond Prices: An Empirical

Assessment

WPS2278 Liquidity Constraints and Investment in Transition Economies: The Case of Bulgaria

WPS2279 Broad Roads in a Thin Country: Infrastructure Concessions in Chile

WPS2280 Willingness to Pay for Air Quality Improvements in Sofia, Bulgaria

WPS2281 External Sustainability: A Stock Equilibrium Perspective

WPS2282 Managing Fiscal Risk in Bulgaria
Author

Nina Budina

Tzvetan Mantchev

Nina Budina

Harry Garretsen

Andrés Gómez-Lobo

Sergio Hinojosa

Hua Wang

Dale Whittington

César Calderón

Norman Loayza

Hana Polackova Brixi

Sergei Shatalov

Leila Zlaoui

\section{Date}

January 2000

January 2000

January 2000

January 2000

January 2000
Contact for paper

N. Budina 82045

N. Budina 82045

G. Chenet-Smith 36370

R. Yazigi 37176

H. Vargas 38546

L. Zlaoui 33100 